\title{
Polyvinyl Pyrrolidone Promotes DNA Cleavage by a ROS- Independent and Depurination Mechanism
}

\author{
Maoyong Song, ${ }^{\dagger}$ Luzhe Zeng, $^{\dagger}$ Xianjun Hong, ${ }^{\dagger} \ddagger$ Zihui Meng, ${ }^{\dagger}$ Junfa Yin, ${ }^{\dagger}$ Hailin Wang, ${ }^{\dagger \dagger}$ Yong Liang, \\ and Guibin Jiang ${ }^{\dagger}$ \\ ${ }^{\dagger}$ State Key Laboratory of Environmental Chemistry and Ecotoxicology, Research Center for Eco-Environmental Sciences, Chinese \\ Academy of Sciences, Beijing 100085, China \\ ${ }^{\ddagger}$ School of Chemical Engineering and Environment, Beijing Institute of Technology, Beijing 100081, China \\ ${ }^{\S}$ School of Medicine, Jianghan University, Hubei Province 430056, China
}

Supporting Information

ABSTRACT: Polyvinyl pyrrolidone polymer (PVP) has been widely applied in biological and medical fields. A few in vitro studies indicated that PVP might cause toxicity. However, the underlying mechanism is poorly understood. In this work, we found that PVP directly induced strand breakages of various DNA molecules, implicating a cleavage activity. Moreover, reactive oxygen species (ROS) scavenging analysis shows that DNA cleavage activity of PVP is not related to ROS-induced

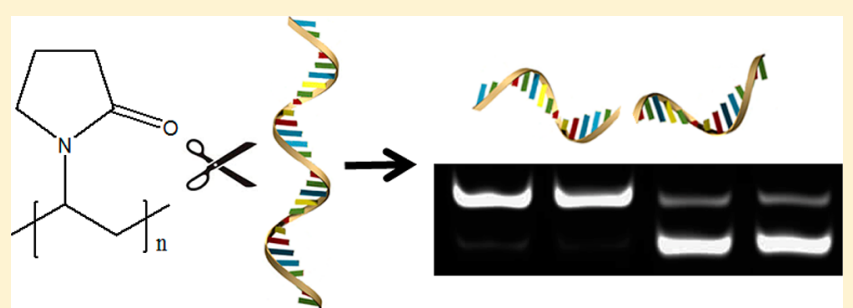
oxidation. As revealed by gel electrophoresis and liquid chromatography/mass spectrometry analysis, the major cleavage products of DNA were identified as two purine bases, guanine and adenine, suggesting that PVPs have a novel depurination activity. The selective depurination and DNA cleavage activity of PVPs were further confirmed by studying the interaction of PVP with four nucleosides and four well-designed oligodeoxynucleotides probes containing specific nucleotides. This study may provide insights into PVP-DNA interactions and resultant genotoxicity and may also open a new way for DNA study.

\section{INTRODUCTION}

Since the sequence of nucleobases along the double helix of DNA codes for the blueprint of organisms, any alteration of the nucleobases may potentially affect genomic integrity. DNA are naturally stable biopolymers with an estimated half-life of 16 million years for spontaneous hydrolysis of phosphodiester bonds under physiological conditions. ${ }^{1}$ However, a series of reactions under physiological conditions could occur and cause the cleavage of DNA molecules, including depurination or depyrimidination, ${ }^{2-4}$ deamination of the nucleobase, ${ }^{5-7}$ and phosphodiester cleavage of the backbone. ${ }^{8,9}$ DNA cleavage may occur by a self-catalyzed mechanism ${ }^{10,11}$ or be facilitated by enzymes. ${ }^{12-14}$ Meanwhile, a variety of agents, including toxin (ricin A-chain), ${ }^{15}$ metallopeptides, ${ }^{16,17}$ antitumor agents, ${ }^{18,19}$ alkylating agents, ${ }^{20,21}$ metal complexes, ${ }^{22,23}$ and nanoparticles, ${ }^{24-26}$ can promote or cause DNA cleavage. The screening of chemicals with an ability to cleave DNA is of intensive interest for evaluation of chemical genotoxicity, exploitation of potential applications in biotechnology, and development for therapeutics.

Polyvinyl pyrrolidone polymers (PVP), as a synthetic watersoluble macromolecular polymers, have been generally used as an excellent pharmaceutical excipients, acting as vehicles for drug and as plasma expanders. ${ }^{27,28}$ They are also used in the production of one of the most important topical disinfectants, PVP-iodine. Recently, PVPs are widely used for the stabilization of nanoparticales by increasing the dispersion and reducing their aggregation in solution. ${ }^{29-31}$ Although some animal studies indicated that PVPs were biological inert, ${ }^{32}$ PVP K30 can induce apoptosis and cell cycle arrest on cultured HeLa cells. $^{33}$ PVP-iodine could cause lung injury and epithelial damage in rats. ${ }^{34,35}$ Moreover, rat peritoneal macrophages, ${ }^{36}$ rat yolk sac, ${ }^{37}$ and hepatocyte ${ }^{38}$ can uptake PVP via pinocytosis. Recently, copolymers conjugated with PVP and hydrophobic segments exhibit a high DNA cleavage activity. ${ }^{39,40}$ However, it is unknown whether PVP can directly induce DNA damage, if so, what is the underlying mechanism.

In this work, we investigated PVP-caused DNA damage and the related mechanism using gel electrophoresis analysis, liquid chromatography/mass spectrometry analysis, and designed DNA probes. This study may provide a framework for understanding the toxicity of PVP. On the other hand, it will also open new applications of PVPs in DNA study.

\section{MATERIALS AND METHODS}

Materials. PVP K40 (99\%, average mol wt 40,000), plasmid DNA pBR322, and fluorescently labeled ssDNA were

Received: November 12, 2012

Revised: February 19, 2013

Accepted: February 20, 2013

Published: February 20, 2013 
purchased and synthesized from Shanghai Sangon Biological Engineering Technology \& Services Co., Ltd., China. Deoxyribonuclease I (DNase I), calf intestinal alkaline phosphatase (CIP), and snake venom phosphodiesterase I were obtained from New England BioLabs (Ipswich, MA, USA). Microcon centrifugal filter devices were obtained from Millipore (Bedford, MA, USA). All solutions were prepared with 18.2 M $\Omega$ distilled deionized water (ALGA system, UK). All other chemicals were analytical grade compounds obtained from commercial sources.

DNA Cleavage Assay. The supercoiled plasmid DNA (pBR322, Shanghai Sangon Biological Engineering Technology \& Services Co., Ltd., China) solution and other reagent solutions were mixed well in Tris- $\mathrm{HCl}$ buffer $(1 \mathrm{M}, \mathrm{pH} 7.0)$. After incubation at given experimental conditions, the mixture was mixed with bromophenol blue-glycerol solution $(5 \mu \mathrm{L})$ and subjected to agarose gel electrophoresis (1\% agarose in TAE buffer, $100 \mathrm{~V}, 30 \mathrm{~min}$ ). The gel was stained with ethidium bromide and photographed on a UV transilluminator for analysis of the ration of Form I (supercoiled DNA) and Form II (nicked DNA). Single-strand DNA was analyzed using 16\% polyacrylamide gel electrophoresis.

DNA Digestion. DNA digestion was performed as described previously. ${ }^{41}$ Plasmid DNA was digested with I U DNase I, $2 \mathrm{U}$ phosphatase alkaline from calf intestine (CIP) and $0.005 \mathrm{U}$ snake venom phosphodiesterase I at $37{ }^{\circ} \mathrm{C}$ for 24 h. Microcon centrifugal filter device with a $3000 \mathrm{Da}$ cutoff membrane was used to remove protein from the digested DNA samples by centrifuging at $12,000 \mathrm{rpm}$ for $60 \mathrm{~min}$.

Identification and Analysis of DNA Hydrolytic Products. The separation of DNA and the released bases was performed with a Hitachi L-2000 HPLC system (Tokyo, Japan), which consists of a L-2130 low-pressure gradient pump, a L-2200 autosampler, and a L-2455 diode array detector (DAD). A Capcell Pak C18 column $(150 \times 4.6 \mathrm{mmID}, 5 \mu \mathrm{m})$ from Shiseido (Tokyo, Japan) was employed for separation. The mobile phase consisting of $4 \%$ acetonitrile and $95 \%$ water (plus $0.1 \%$ Formic Acid) was used for HPLC separation of nucleosides and bases. The flow-rate was $1.2 \mathrm{~mL} / \mathrm{min}$ and injection volume was $20 \mu \mathrm{L}$. UV detection was set at $254 \mathrm{~nm}$.

An Agilent 6410B Triple Quadrupole mass spectrometer (Santa Clara, CA, USA) with an electrospray ionization source was applied for mass spectrometric detection. Mass spectrometry conditions were optimized as follows: ionization mode, ESI-positive; capillary voltage, $3500 \mathrm{~V}$; nitrogen drying gas temperature, $300{ }^{\circ} \mathrm{C}$; drying gas flow, $9 \mathrm{~L} / \mathrm{min}$; nebulizer, 40 psi. For MS/MS analysis of nucleosides and bases, the fragmentor voltage was $90 \mathrm{~V}$, collision energy was performed at $5 \mathrm{eV}$, and scan time was $100 \mathrm{~ms}$.

\section{RESULTS AND DISCUSSION}

DNA Cleavage by PVP. We first tested the DNA cleavage activity of PVPs using pBR322 supercoiled DNA. As shown in Figure 1, pBR322 DNA (Form I) was efficiently cleaved into nicked DNA (Form II) in the presence of 1\% PVP after $18 \mathrm{~h}$ incubation at $37{ }^{\circ} \mathrm{C}$ (lane 3). In the absence of PVP, plasmid DNA had no obvious changes comparing with the control (lane 2 ). In this experiment, PVP was dissolved in water, and then the $\mathrm{pH}$ decreased down to 6.4 (lanes 1-3). It is not known whether such an acidic condition can cause DNA hydrolysis, which leads to strand breakage. To exclude this possibility, we further dissolved DNA and PVP using a neutral buffer (Tris$\mathrm{HCl}, \mathrm{pH}$ 7.0). However, the plasmid DNA was also cleaved

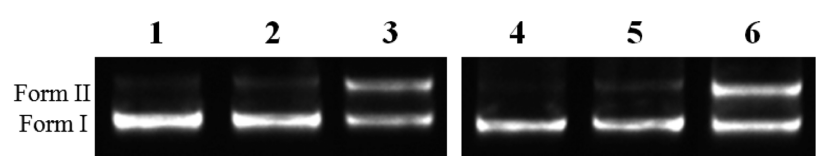

Figure 1. Cleavage of pBR322 plasmid DNA by PVP. Reactions performed in water (lanes 1-3) and in Tris- $\mathrm{HCl}$ buffer $(10 \mathrm{mM}, \mathrm{pH}$ 7.0, lanes 4-6). Lanes 1 and 4, fresh DNA; lanes 2 and 5, DNA was incubated without PVP for $18 \mathrm{~h}$ at $37^{\circ} \mathrm{C}$; lanes 3 and 6, DNA was incubated with PVP (1\%) for $18 \mathrm{~h}$ at $37^{\circ} \mathrm{C}$.

into the nicked DNA by PVP under neutral conditions (lanes 5 and 6, Figure 1). The results indicate that PVP may possess unique DNA cleavage activity.

Mechanism of DNA Cleavage by PVP. It is well-known that reactive oxygen species (ROS) can cause DNA damage, including DNA cleavage. ${ }^{42,43}$ So we first investigated whether the PVP-DNA cleavage is induced by the generation of ROS. A hydroxyl radical scavenger (DMSO) and a singlet oxygen quencher (sodium azide) were added to eliminate the effects of hydroxyl radical and singlet oxygen, respectively. Surprisingly, no inhibition on DNA cleavage (Figure 2a) was observed, indicating that the PVP-caused DNA cleavage cannot be attributed to the generation of hydroxyl radical and singlet oxygen, the two most reactive species of ROS. ${ }^{26}$

DNA (treated with and without PVP) was first digested by DNase, CIP, and snake venom phosphodiesterase I and then analyzed by a high-performance liquid chromatography-ultraviolet detection (HPLC-UV). HPLC-UV analysis shows that DNA molecules could be effectively digested by enzymes to mononucleosides (Figure 2b). Comparing with control DNA (Trace 2, treated at $90{ }^{\circ} \mathrm{C}$ without PVP), a new characteristic peak (P1, $14.9 \mathrm{~min})$ appeared, and the peak of deoxycytidine (dC) was obviously increased. Interestingly, two new peaks (P1 and P2) could be observed from direct HPLC-UV analysis of PVP-treated DNA, in which DNA was not enzymatically digested to mononucleosides (Figure $2 b$, trace 3 ). The peak P2 has same retention as $\mathrm{dC}$. In contrast, no P1 and P2 were observed for DNA without PVP treatment (Figure 2a, trace 4). Therefore, the two new peaks (P1 and P2) should be attributed to the products released from dsDNA after treated with PVP. The two products were further identified using LC-ESI-MS/ MS. The MS/MS spectrum of P1 shows three fragment ions at $m / z 136.1,119.0$, and 92.0. The presence of fragment ion at $m /$ $z 136.1$ suggests that $\mathrm{P} 1$ is the $[\mathrm{M}+\mathrm{H}]^{+}$peak for adenine (Figure 2c)..$^{44,45}$ The fragmentation spectrum shows major fragment ions from a loss of $\mathrm{NH}_{3}$ at $\mathrm{m} / z 119$ and one minor fragment $\left(\mathrm{CN}_{2} \mathrm{H}_{4}\right)$ at $m / z 92$. Similarly, the MS/MS spectrum of P2 shows three fragment ions at $m / z 152.2,135.0$ and 110.1, and the presence of fragment ion at $m / z 152.2$ suggests that P2 is the $[\mathrm{M}+\mathrm{H}]^{+}$peak for guanine (Figure $2 \mathrm{~d}$ ). ${ }^{46,47}$ The release of these nucleobases from dsDNA suggests that the $\mathrm{N}$ glycosidic bond can be broken down by PVP during DNA cleavage. Therefore, we demonstrate that PVPs have an intrinsic activity similar to that of DNA glycosylases, which can hydrolyze bases from nucleosides or DNA.

Depurination of Nucleosides by PVP. To further characterize the hydrolysis activity of PVP, we performed the experiments using mononucleosides as substrates instead of supercoiled plasmid dsDNA. Four types of mononucleosides were incubated with PVP at 30 and $90{ }^{\circ} \mathrm{C}$ for $60 \mathrm{~min}$. The levels of mononucleosides and the released bases were measured by HPLC-UV analysis. As shown in Figure 3, PVP can hydrolyze guanine and adenine from nucleosides easily; 


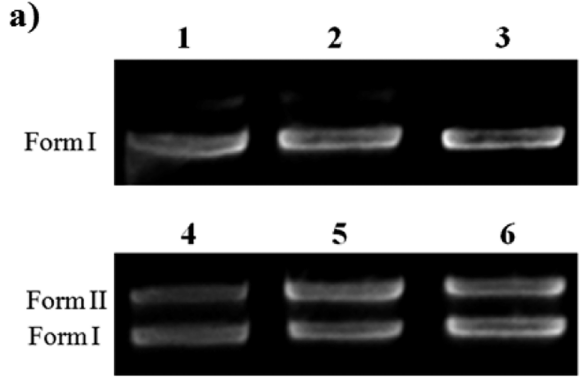

c)

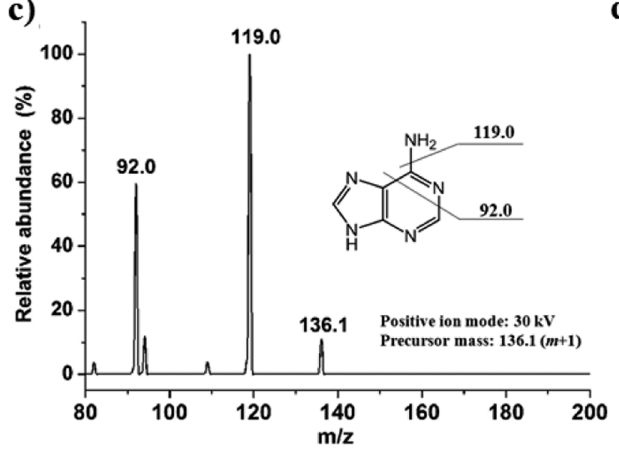

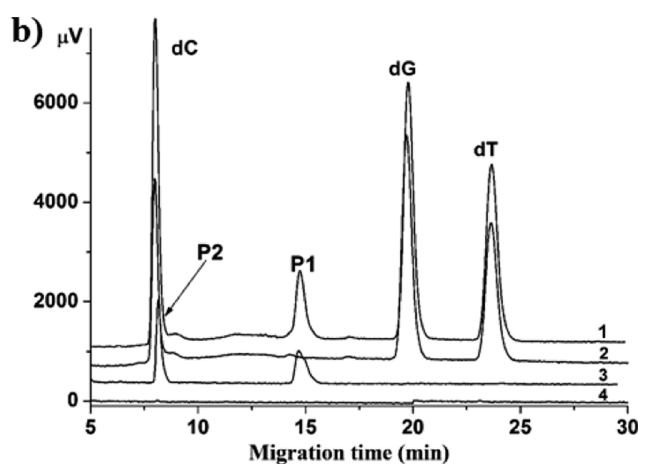

d)

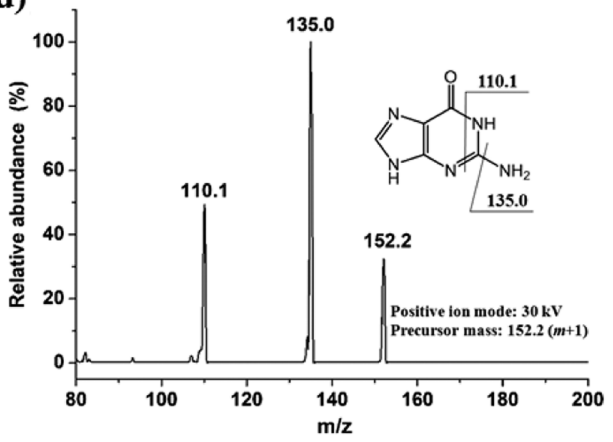

Figure 2. (a) Effects of DMSO and sodium azide on the DNA cleavage by PVP. All samples were incubated for $18 \mathrm{~h}$ at $37^{\circ} \mathrm{C}$. Lanes $4-6$, with PVP (1\%); lanes 2 and 5, with DMSO (25 mM); lanes 3 and 6, with sodium azide (25 mM). (b) HPLC separation of reaction products of DNA and PVP. Traces 1 and 2, enzyme-digested DNA; Traces 3 and 4, none-enzyme-digested DNA. Traces 1 and 3, DNA $\left(20 \mu \mathrm{g} \mathrm{mL}^{-1}\right)$ with PVP $(1 \%)$ was incubated for $10 \mathrm{~min}$ at $90^{\circ} \mathrm{C}$. (c) ESI-MS/MS product ion spectra of $[\mathrm{M}+\mathrm{H}]^{+} \mathrm{m} / z 136.1$ for P1; (d) ESI-MS/MS product ion spectra of $[\mathrm{M}+$ $\mathrm{H}]^{+} m / z 152.2$ for P2.

whereas only a little of cytosine was released from $\mathrm{dC}$, and no thymine was detected after incubating $\mathrm{dT}$ with PVP. The results clearly show that the hydrolysis activity of PVP is basespecific. The release of bases from DNA and mononucleosides by PVP can be enhanced by incubation temperature. It is apparent that few bases were detected when nucleotide incubated with PVP at $30{ }^{\circ} \mathrm{C}$ (Figure 3, lane 2), but the yields of bases (guanine and adenine) are largely enhanced when the incubation temperature increases to $90^{\circ} \mathrm{C}$.

Selective Cleavage of ssDNA by PVP. As described above, PVP can hydrolyze purine bases from DNA and exhibit an intrinsic depurination activity, which then leads to DNA cleavage. In order to confirm this observation, we investigated the interaction between PVP and designed ssDNA probes. Four types of fluorescently labeled ssDNA probes were designed to have a $50 \mathrm{bp}$ long poly $\mathrm{T}$ chain but with single specific nucleotide at the 40th nucleotide site (Figure 4). After having been incubated with PVP for $60 \mathrm{~min}$ at $90{ }^{\circ} \mathrm{C}$, the ssDNA probes were analyzed by $16 \%$ polyacrylamide gel electrophoresis. Figure 4 shows the cleaving activity of PVP and changes of ssDNA probes. Probe 1 (polyT) and probe 2 (polyT- $\mathrm{C}_{40}$ ) were not cleaved at all and kept the integrity of DNA chains. However, a new band with a length of 39 bp was emerged on the gel when probe 3 (polyT- $\mathrm{G}_{40}$ ) and probe 4 (polyT- $\mathrm{A}_{40}$ ) were treated with PVP, respectively. The results indicate that probes 3 and 4 were cleaved by PVP at the site of $\mathrm{G}_{40}$ and $\mathrm{A}_{40}$, respectively. The HPLC-UV analysis shows a significant increase of adenine and guanine in PVP-treated probes 3 and 4 (Figure S1), confirming that PVP can cleave DNA chains through its base-specific hydrolytic activity.

To examine the actual role of PVP on the DNA cleavage, PVP was dialyzed $24 \mathrm{~h}$ using semipermeable membrane (Intercepted Molecular Weight as 3,000) to remove the monomer of the PVP or any other impurities. The purified PVPs also exhibited a DNA cleavage activity after dialysis (Figure S2), which indicates that PVPs can act as DNA cleaver in the form of ploymers. As a class of polymers, the impact of the molecular weight of PVPs on the DNA cleavage should be taken into account. Here we compared the DNA-cleaving activity of five types of PVPs with different average molecular weight from 8,000 to 63,000 Da. All PVPs exhibited cleavage activity on both dsDNA and ssDNA (Figure S3). For plasmid DNA, PVP1 (average molecular weight: 8,000 Da) shows the strongest cleavage activity as the supercoiled form I almost disappeared on the gel. However when incubated with ssDNA, PVP 3 (average molecular weight: 40,000 Da) has the strongest cleavage activity. Although PVPs of different molecular weight show different DNA cleavage activity, what is confirmed is that the breakage of DNA selectively occurs at G and A sites (Figure S3).

Depurination is the loss of a purine base as a consequence of $\mathrm{N}$-glycosidic bond cleavage. Nonenzymatic N-glycoside hydrolyses have been characterized in detail in nucleosides and in DNA. ${ }^{5,12,48}$ These reactions are acid-catalyzed hydrolysis. Most researchers have favored the following pathway. The sugar ring oxygen is protonated, either directly or by proton transfer from the nitrogen heterocycle. The glycosidic nitrogen then participates in sugar ring-opening. This is followed by attack of water and the cleavage of the heterocycle from the openchain sugar. An alternative path is direct cleavage of the heterocycle from the protonated nucleoside ( $\mathrm{C}-\mathrm{N}$ cleavage). ${ }^{48}$ Alkylation of the N7 position of guanine residues in DNA places a positive charge on the guanine ring system and greatly increases the rate of depurination. ${ }^{49}$ In this work, guanine and adenine are cleaved from nucleoside and DNA after having been incubated with PVP. Given positively charged nitrogen in 

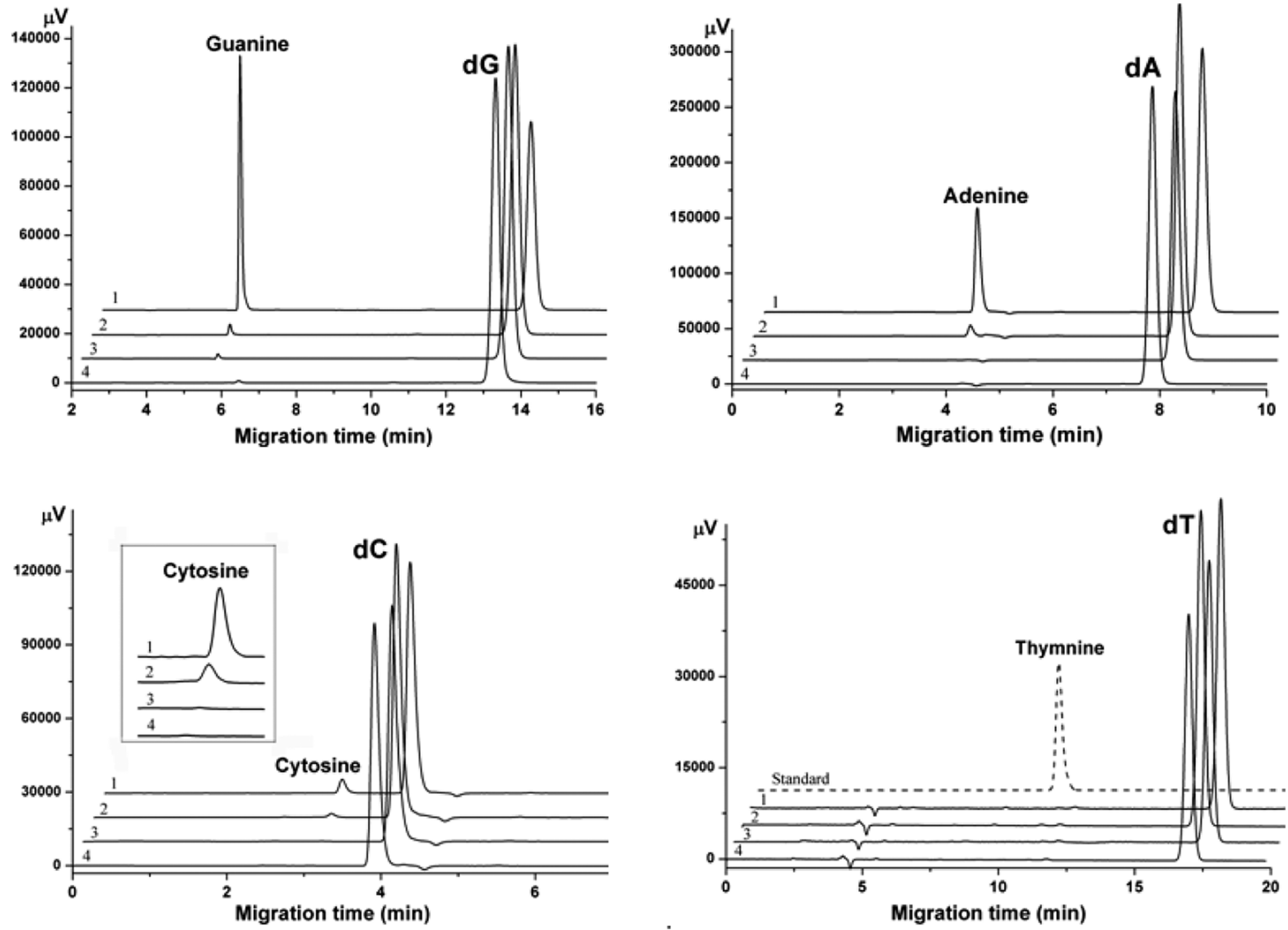

Figure 3. Chromatograms obtained from HPLC-UV analysis of the reaction mixtures of four mononucleosides (2 mM) with or without PVP (1\%). Trace 1, nucleosides incubated for $60 \mathrm{~min}$ at $30^{\circ} \mathrm{C}$; Trace 2, nucleosides and PVP incubated at for $60 \mathrm{~min} 30^{\circ} \mathrm{C}$; Trace 3, nucleosides incubated at for $60 \mathrm{~min} 90^{\circ} \mathrm{C}$; Trace 4, nucleosides and PVP incubated at for $60 \mathrm{~min} 90{ }^{\circ} \mathrm{C}$; Dash lane, standard of thymine.

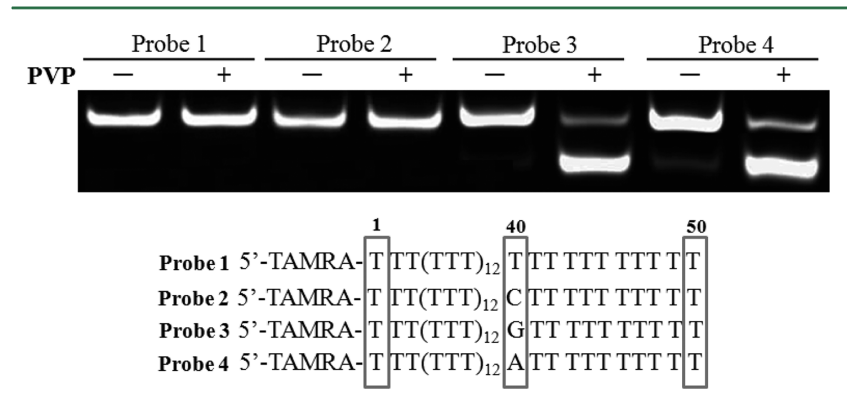

Figure 4. ssDNA probes cleavage by PVP. The probes $(5 \mu \mathrm{M})$ were incubated with PVP (1\%) in Tris-HCl buffer ( $\mathrm{pH} 7.0)$ for 60 min at 90 ${ }^{\circ} \mathrm{C}$.

PVP, ${ }^{50}$ it is probably due to the fact that the N7 positions of guanine and adenine are transiently alkylated by PVP, which may place a positive charge on the guanine or adenine ring system and greatly increase the rate of depurination. However, the exact depurination mechanism remains to be explored.

Fullerenes can generate ROS when irradiated with UV or visible light, which can cause plasmid DNA cleavage. ${ }^{26} \mathrm{PVP}$, as cosolvent or stabilizer of fullerene nanoparticles, was considered as a key role on the formation of ROS when photoexcited. ${ }^{51}$ However, the DNA cleavage activity of PVP was ignored or unperceived in previous work. A possible reason is that previous experiments were carried out at a lower temperature and for a shorter incubation time, but the DNA cleavage and base hydrolysis of PVP are highly dependent on incubation time and temperature. For example, the disappeared time of form II DNA is 3 days when incubated DNA with PVP at $37^{\circ} \mathrm{C}$, but it is just $5 \mathrm{~min}$ when the incubation temperature is set at $90{ }^{\circ} \mathrm{C}$ (Figure S4). Our results demonstrate that the fullerene solution containing PVP can cleave plasmid DNA without irradiation of UV or visible light, but fullerene without PVP does not exhibit DNA cleavage activity under the same reaction condition (Figure S5). This finding may also implicate that PVP might play an important role on the potential toxicity of PVP-stabilizing nanoparticles. On the other hand, although the DNA cleavage by PVP is a slow process at room temperature, it needed to be pointed out that more and more guanine and adenine are released from DNA promoted by PVP with prolonged incubation (Figure 5). It indicates that this process represents a threat to genome stability if occurring in organisms.

In conclusion, we demonstrate a DNA cleavage activity of PVP. Rather than ROS-mediated oxidation mechanism, the cleavage is found to be mainly due to a selective hydrolysis of $\mathrm{N}$-glycosidic bonds of guanine and adenine promoted by PVP. Since the DNA cleavage in vivo may lead to mutation or activation of the DNA via chain breakage, the observed DNA cleavage may provide a framework for understanding the potential toxicity of PVP. 


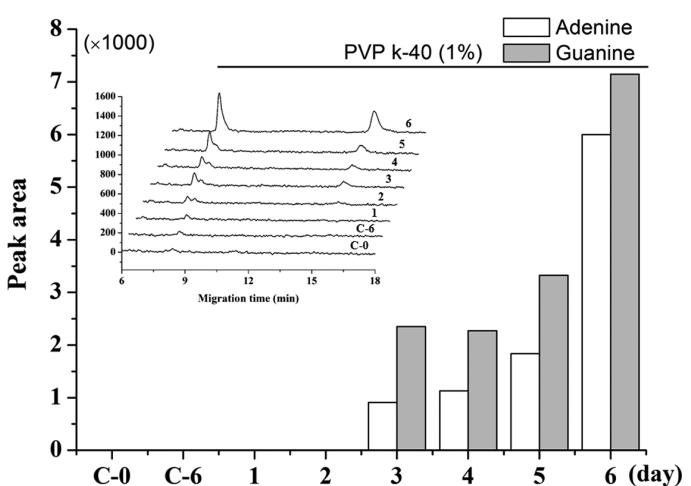

Figure 5. Depurination of DNA promoted by PVP during 6 days incubation. Trace C-0, control DNA for 0 day; Trace C-6, DNA without PVP incubated for 6 days at $37{ }^{\circ} \mathrm{C}$; Traces $1-6$, DNA incubated with PVP (1\%) from 1 to 6 days at $37^{\circ} \mathrm{C}$. Insert figure is HPLC chromatogram of adenine and guanine in each sample.

\section{ASSOCIATED CONTENT}

\section{S Supporting Information}

Mobility-shift gel electrophoresis analysis of the cleavage of ssDNA probes and guanine and adenine production analyzed by HPLC-UV detection (Figure S1); cleavage of ssDNA probes by purified PVP (Figure S2); DNA cleavage by PVPs with different average molecular weight (Figure S3); cleavage of pBR322 DNA by PVP (1\%) at 37 and $90{ }^{\circ} \mathrm{C}$ (Figure S4); DNA cleavage by $\mathrm{nC}_{60}, \mathrm{PVP}$, and $\mathrm{nC}_{60}$ containing PVP (Figure S5). This material is available free of charge via the Internet at http://pubs.acs.org.

\section{AUTHOR INFORMATION}

\section{Corresponding Author}

*Phone/Fax: 0086-10-62849600. E-mail: hlwang@rcees.ac.cn.

\section{Notes}

The authors declare no competing financial interest.

\section{ACKNOWLEDGMENTS}

This work was supported by the National Natural Science Foundation of China (Nos. 21077116, 21125523, and 20921063) and the grants from the National Basic Research Program of China (Nos. 10CB933502, 11CB936001).

\section{REFERENCES}

(1) Westheimer, F. H. Why nature chose phosphates. Science 1987, $235,1173-1178$.

(2) Lindahl, T.; Nyberg, B. Heat-induced deamination of cytosine residues in deoxyribonucleic acid. Biochemistry 1974, 13, 3405-3410.

(3) Lindahl, T. Instability and decay of the primary structure of DNA. Nature 1993, 362, 709-715.

(4) Nakamura, J.; Walker, V. E.; Upton, P. B.; Chiang, S. Y.; Kow, Y. W.; Swenberg, J. A. Highly sensitive apurinic/apyrimidinic site assay can detect spontaneous and chemically induced depurination under physiological conditions. Cancer Res. 1998, 58, 222-225.

(5) Suzuki, T.; Ide, H.; Yamada, M.; Endo, N.; Kanaori, K.; Tajima, K.; Morii, T.; Makino, K. Formation of 2'-deoxyoxanosine from $2^{\prime}$ deoxyguanosine and nitrous acid: mechanism and intermediates. Nucleic Acids Res. 2000, 28, 544-551.

(6) Hodgen, B.; Rayat, S.; Glaser, R. Nitrosative adenine deamination: facile pyrimidine ring-opening in the dediazoniation of adeninediazonium ion. Org. Lett. 2003, 5, 4077-4080.

(7) Shen, J. C.; Rideout, W. M., 3rd; Jones, P. A. The rate of hydrolytic deamination of 5-methylcytosine in double-stranded DNA. Nucleic Acids Res. 1994, 22, 972-976.
(8) Ho, E. L.; Parent, M.; Satoh, M. S. Induction of base damages representing a high risk site for double-strand DNA break formation in genomic DNA by exposure of cells to DNA damaging agents. J. Biol. Chem. 2007, 282, 21913-21923.

(9) Li, Z.; Zheng, Y.; Cloutier, P.; Sanche, L.; Wagner, J. R. Low energy electron induced DNA damage: effects of terminal phosphate and base moieties on the distribution of damage. J. Am. Chem. Soc. 2008, 130, 5612-5613.

(10) Amosova, O.; Kumar, V.; Deutsch, A.; Fresco, J. R. Selfcatalyzed site-specific depurination of $\mathrm{G}$ residues mediated by cruciform extrusion in closed circular DNA plasmids. J. Biol. Chem. 2011, 286, 36322-36330.

(11) Amosova, O.; Smith, A.; Fresco, J. R. The consensus sequence for self-catalyzed site-specific $\mathrm{G}$ residue depurination in DNA. J. Biol. Chem. 2011, 286, 36316-36321.

(12) Schroeder, G. K.; Wolfenden, R. Rates of spontaneous disintegration of DNA and the rate enhancements produced by DNA glycosylases and deaminases. Biochemistry 2007, 46, 1363813647.

(13) Singh, V.; Schramm, V. L. Transition-state structure of human 5 '-methylthioadenosine phosphorylase. J. Am. Chem. Soc. 2006, 128, 14691-14696.

(14) Zharkov, D. O. Base excision DNA repair. Cell. Mol. Life Sci. 2008, 65, 1544-1565.

(15) Chen, X. Y.; Berti, P. J.; Schramm, V. L. Transition-state analysis for depurination of DNA by ricin A-chain. J. Am. Chem. Soc. 2000, 122, $6527-6534$

(16) Fang, Y. Y.; Claussen, C. A.; Lipkowitz, K. B.; Long, E. C. Diastereoselective DNA cleavage recognition by $\mathrm{Ni}(\mathrm{II}) \mathrm{x}$ Gly-Gly-Hisderived metallopeptides. J. Am. Chem. Soc. 2006, 128, 3198-3207.

(17) Kovacic, R. T.; Welch, J. T.; Franklin, S. J. Sequence-selective DNA cleavage by a chimeric metallopeptide. J. Am. Chem. Soc. 2003, $125,6656-6662$.

(18) Ma, Q.; Akiyama, Y.; Xu, Z.; Konishi, K.; Hecht, S. M. Identification and cleavage site analysis of DNA sequences bound strongly by bleomycin. J. Am. Chem. Soc. 2009, 131, 2013-2022.

(19) Zuber, G.; Quada, J. C.; Hecht, S. M. Sequence selective cleavage of a DNA octanucleotide by chlorinated bithiazoles and bleomycins. J. Am. Chem. Soc. 1998, 120, 9368-9369.

(20) Lönnberg, H.; Lehikoinen, P. Mechanisms for the solvolytic decompositions of nucleoside analogues. X. Acidic hydrolysis of 6substituted 9-(beta-D-ribofuranosyl)purines. Nucleic Acids Res. 1982, 10, 4339-4349.

(21) Rios-Font, R.; Rodríguez-Santiago, L.; Bertran, J.; Sodupe, M. Influence of N7 protonation on the mechanism of the N-glycosidic bond hydrolysis in $2^{\prime}$-deoxyguanosine. A theoretical study. J. Phys. Chem. B 2007, 111, 6071-6077.

(22) Arjmand, F.; Parveen, S.; Afzal, M.; Shahid, M. Synthesis, characterization, biological studies (DNA binding, cleavage, antibacterial and topoisomerase I) and molecular docking of copper(II) benzimidazole complexes. J. Photochem. Photobiol., B 2012, 114, 1526.

(23) Zhou, C. Q.; Lin, Y. L.; Chen, J. X.; Chen, W. H. Synergetic DNA-cleaving activities of the metal complexes of a polyether-tethered pyrrole-polyamide dimer. Chem. Biodivers. 2012, 9, 1125-1132.

(24) Zhou, C.; Liu, Q.; Xu, W.; Wang, C.; Fang, X. A water-soluble $\mathrm{C}_{60}$-porphyrin compound for highly efficient DNA photocleavage. Chem. Commun. 2011, 47, 2982-2984.

(25) Ikeda, A.; Doi, Y.; Hashizume, M.; Kikuchi, J.; Konishi, T. An extremely effective DNA photocleavage utilizing functionalized liposomes with a fullerene-enriched lipid bilayer. J. Am. Chem. Soc. 2007, 129, 4140-4141.

(26) Yamakoshi, Y.; Umezawa, N.; Ryu, A.; Arakane, K.; Miyata, N.; Goda, Y.; Masumizu, T.; Nagano, T. Active oxygen species generated from photoexcited fullerene $\left(\mathrm{C}_{60}\right)$ as potential medicines: $\mathrm{O}^{2 \cdot \bullet}$ versus ${ }^{1} \mathrm{O}_{2}$. J. Am. Chem. Soc. 2003, 125, 12803-12809.

(27) Ravin, H. A.; Seligman, A. M.; Fine, J. Polyvinylpyrrolidone as a plasma expander: studies on its excretion, distribution, and metabolism. N. Engl. J. Med. 1952, 247, 921-929. 
(28) Mu, Y.; Kamada, H.; Kodaira, H.; Sato, K.; Tsutsumi, Y.; Maeda, M.; Kawasaki, K.; Nomizu, M.; Yamada, Y.; Mayumi, T. Bioconjugation of laminin-related peptide YIGSR with polyvinylpyrrolidone increases its antimetastatic effect due to a longer plasma halflife. Biochem. Biophys. Res. Commun. 1999, 264, 763-767.

(29) Masingboon, C.; Maensiri, S.; Yamwong, T. $\mathrm{CaCu}_{3} \mathrm{Ti}_{4} \mathrm{O}_{12}$ nanoparticles using polyvinyl pyrrolidone: synthesis and dielectric properties. J. Nanosci. Nanotechnol. 2011, 11, 8670-8676.

(30) Narayanan, R; El-Sayed, M. A. Effect of colloidal catalysis on the nanoparticle size distribution: dendrimer-Pd vs. PVP-Pd nanoparticles catalyzing the suzuki coupling reaction. J. Phys. Chem. B 2004, 108, 8572-8580.

(31) Pastoriza-Santos, I.; Liz-Marzán, L. M. Formation of PVPprotected metal nanoparticles in DMF. Langmuir 2002, 18, 28882894.

(32) Robinson, B. V.; Sullivan, F. M.; Borzelleca, J. F.; Schwartz, S. L. PVP-A critical review of the kinetics and toxicology of polyvinylpyrrolidone (povidone); Lewis: New York, 1990.

(33) Wang, Y. B.; Lou, Y.; Luo, Z. F.; Zhang, D. F; Wang, Y. Z. Induction of apoptosis and cell cycle arrest by polyvinylpyrrolidone $\mathrm{K}$ 30 and protective effect of a-tocopherol. Biochem. Biophys. Res. Commun. 2003, 308, 878-884.

(34) Cheong, S. H.; Yang, Y. I.; Choi, M. Y.; Kim, M. H.; Cho, K. R.; Lim, S. H.; Lee, J. H.; Lee, K. M.; Moon, S. H. Lung injury induced by the pulmonary instillation of povidone-iodine in rats. J. Anesth. 2012, 26, 70-79.

(35) Jiang, J.; Wu, M.; Shen, T. The toxic effect of different concentrations of povidone iodine on the rabbit's cornea. Cutaneous Ocul. Toxicol. 2009, 28, 119-124.

(36) Pratten, M. K.; Lloyd, J. B. Effects of temperature, metabolic inhibitors and some other factors on fluid-phases and adsorptive pinocytosis by rat peritoneal macrophages. Biochem. J. 1979, 180, 567-571.

(37) Robert, A. V.; Williams, K. E.; Lloyd, J. B. The pinocytosis of ${ }^{125}$ I labelled poly(vinylpyrrolidone), $\left[{ }^{14} \mathrm{C}\right]$ sucrose and colloidal $\left[{ }^{198} \mathrm{Au}\right]$ gold by rat yolk sac cultured in vitro. Biochem. J. 1977, 168, 239-244.

(38) Munniksma, J.; Noteborn, M.; Kooistra, T.; Stienstra, S.; Bouma, J. M.; Gruber, M.; Brouwer, A.; Praaning-van, D. D. D.; Knook, D. L. Fluid endocytosis by rat liver and spleen. Experiments with ${ }^{124} \mathrm{I}$ - labelled poly(vinylpyrrolidone) in vivo. Biochem. J. 1980, 192, 613-621.

(39) Zhang, L. F.; Liang, Y.; Meng, L. Z.; Wang, C. Characterization of complexation of PVP copolymer with DNA. Polym. Adv. Technol. 2009, 20, 410-415.

(40) Zhang, L. F.; Liang, Y.; Meng, L. Z. Cleavage activity of PVP amphiphilic block copolymer for supercoiled DNA. Acta Chim. Sin. 2011, 69, 1941-1945.

(41) Wang, X. L.; Suo, Y. S.; Yin, R. C.; Shen, H. Q.; Wang, H. L. Ultra-performance liquid chromatography/tandem mass spectrometry for accurate quantification of global DNA methylation in human sperms. J. Chromatogr., B 2011, 879, 1647-1652.

(42) Wiseman, H.; Halliwell, B. Damage to DNA by reactive oxygen and nitrogen species: role in inflammatory disease and progression to cancer. Biochem. J. 1996, 313, 17-19.

(43) De Bont, R; van Larebeke, N. Endogenous DNA damage in humans: a review of quantitative data. Mutagenesis 2004, 19, 169-185.

(44) Van Dycke, A.; Verstraete, A.; Pil, K.; Raedt, R; Vonck, K.; Boison, D.; Boon, P. Quantitative analysis of adenosine using Liquid Chromatography/Atmospheric Pressure Chemical Ionization-tandem Mass Spectrometry (LC/APCI-MS/MS). J. Chromatogr., B 2010, 878, 1493-1498.

(45) Nelson, C. C.; McCloskey, J. A. Collision-induced dissociation of adenine. J. Am. Chem. Soc. 1992, 114, 3661-3668.

(46) Gregson, J. M.; McCloskey, J. A. Collision-induced dissociation of protonated guanine. Int. J. Mass Spectrom. Ion Processes 1997, 165/ $166,475-485$.

(47) Sherchan, J.; Lee, E. S. Deguanylation of guanine basednucleosides and calf thymus DNA induced by halogenated alkanes at the physiological condition. Bull. Korean Chem. Soc. 2009, 30, 29492958.

(48) Shapiro, R.; Danzig, M. Acid hydrolysis of deoxycytidine and deoxyuridine derivatives. The general mechanism of deoxuribonucleoside hydrolysis. Biochemistry 1972, 11, 23-29.

(49) Gates, K. S.; Nooner, T.; Dutta, S. Biological relevant chemical reaction of N7-alkygunine residues in DNA. Chem. Res. Toxicol. 2004, $17,839-856$.

(50) Tachikawa, S.; Noguchi, A.; Tsuge, T.; Hara, M.; Odawara, O.; Wada, $\mathrm{H}$. Optical properties of $\mathrm{ZnO}$ nanoparticles capped with polymers. Materials 2011, 4, 1132-1143.

(51) Lee, J.; Yamakoshi, Y.; Hughes, J. B.; Kim, J. H. Mechanism of $\mathrm{C}_{60}$ photoreactivity in water: fate of triplet state and radical anion and production of reactive oxygen species. Environ. Sci. Technol. 2008, 42, 3459-3464. 